\title{
Front Matter: Volume 11528
}

, "Front Matter: Volume 11528," Proc. SPIE 11528, Remote Sensing for Agriculture, Ecosystems, and Hydrology XXII, 1152801 (13 October 2020); doi: $10.1117 / 12.2584634$

SPIE. Event: SPIE Remote Sensing, 2020, Online Only 


\title{
PRO CEEDINGS OF SPIE
}

\section{Remote Sensing for Agric ulture, Ecosystems, and Hydrology XXII}

\author{
Christopher M. U. Neale \\ Antonino Maltese \\ Editors
}

22-25 September 2020

Online Only, United Kingdom

Sponsored by

SPIE

Cooperating Organisations

European Optical Soc iety

KTN-Knowledge Transfer Network (United Kingdom)

Technology Sc otland (United Kingdom)

Visit Scotland (United Kingdom)

BARSC - British Association of Remote Sensing (United Kingdom)

EARSeL-European Association of Remote Sensing Laboratories (Gemany)

ISPRS-Intemational Society for Photogrammetry and Remote Sensing

Published by

SPIE

Volume 11528 
The papers in this volume were part of the technical conference cited on the cover and title page. Papers were selected and subject to review by the editors and conference program committee. Some conference presentations may not be available for publication. Additional papers and presentation recordings may be available online in the SPIE Digital Libra ry at SPIEDigita lLibrary.org.

The papers reflect the work and thoughts of the authors and are published herein as submitted. The publisher is not responsible for the validity of the information or for any outcomes resulting from reliance thereon.

Please use the following format to cite material from these proceedings:

Author(s), "Title of Paper," in Remote Sensing for Agric ulture, Ecosystems, and Hydrology XXII, edited by Christopher M. U. Neale, Antonino Maltese, Proceedings of SPIE Vol. 11528 (SPIE, Bellingham, WA, 2020) Seven-digit Artic le CID Number.

ISSN: 0277-786X

ISSN: 1996-756X (electronic)

ISBN: 9781510638693

ISBN: 9781510638709 (electronic)

Published by

SPIE

P.O. Box 10, Bellingham, Washington 98227-0010 USA

Telephone +1 3606763290 (Pacific Time)· Fax +1 3606471445

SPIE.org

Copyright (c) 2020, Society of Photo-Optic al Instrumentation Engineers.

Copying of material in this book for intemal or personal use, or for the intemal or personal use of specific clients, beyond the fair use provisions granted by the U.S. Copyright Law is authorized by SPIE subject to payment of copying fees. The Transactional Reporting Service base fee for this volume is $\$ 21.00$ per article (or portion thereof), which should be paid directly to the Copyright Clearance Center (CCC), 222 Rosewood Drive, Danvers, MA 01923. Payment may also be made electronically through CCC Online at copyright.com. Other copying for republication, resale, advertising or promotion, or any form of systematic or multiple reproduction of any material in this book is prohibited except with pemission in writing from the publisher. The CCC fee code is 0277$786 \times / 20 / \$ 21.00$.

Printed in the United States of Americ a by Curran Associates, Inc., under lic ense from SPIE.

Public ation of record for individual papers is online in the SPIE Digital Library.

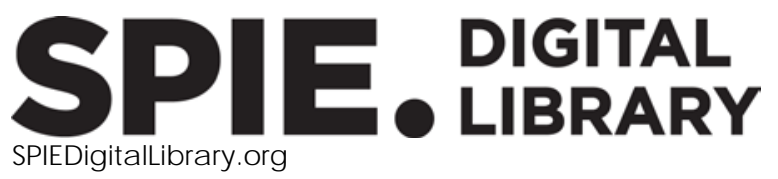

Paper Numbering: Proceedings of SPIE follow an e-First publication model. A unique citation identifier (CID) number is assigned to each article at the time of publication. Utilization of CIDs allows articles to be fully citable as soon as they are published online, and connects the same identifier to all online and print versions of the publication. SPIE uses a seven-digit CID article numbering system structured as follows:

- The first five digits correspond to the SPIE volume number.

- The last two digits indicate publication order within the volume using a Base 36 numbering system employing both numerals and letters. These two-number sets start with $00,01,02,03,04$, 05, 06, 07, 08, 09, 0A, 0B ... 0Z, followed by 10-1Z, 20-2Z, etc. The CID Number appears on each page of the manuscript. 


\section{Contents}

SENTINEL-2

1152804 Application of geospatial technology for high-resolution mapping and monitoring of crop pattems in support of crop insurance for the rain-fed regions of India [11528-1]

1152806 Application of principal component analysis to remote sensing data for deforestation monitoring [11528-3]

1152807 Monitoring of soil moisture in the south of Ukraine using active and passive remote sensing data [11528-4]

\section{PRECISION FARMING}

1152808 Temporal analysis of the vineyard phenology from remote sensing data using Google Earth engine [11528-5]

1152809 Famland segmentation from remote sensing images using deep leaming methods [11528-6]

$11528 \mathrm{OA}$ Initial evaluation of enriching satellite imagery using sparse proximal sensing in precision farming [11528-7]

$11528 \mathrm{OB} \quad$ Predictive modelling of wheat yield from vegetation index time series in Spain: assessing the use of Corine Land Cover and CAP statistics to obtain crop masks [11528-8]

11528 OC An integrated senvice-based solution addressing the modemised common agriculture policy regulations and environmental perspectives [11528-9]

\section{HYDROLOGY}

11528 OE Fash flood susceptibility modeling for drainage basins of Dir Lower Khyber-Pakhtunkhwa: a comparative analysis of momhometric ranking and E-Shamy's approach [11528-11]

11528 0] Modelling resenoir turbidity from medium resolution Sentinel-2A/MSI and Landsat-8/OU satellite imagery [11528-37]

\section{VEGETATION MONITORING}

11528 OK Vegetation phenology dynamics across ecoregions of Iberian Peninsula from MODIS NDVI time series: 2001-2017 [11528-16] 
$11528 \mathrm{OL} \quad$ Emissivity-based vegetation indices to monitor deforestation and forest degradation in the Congo basin rainforest [11528-17]

11528 OM Detecting leaf phosphonus content in arbusc ular myconhizal fungi-inoculated soybean using hyperspectral remote sensing data [11528-18]

\section{ECOSYSTEM AND ENVIRONMENTALCHANGES}

1152800 An approach for forewaming forest fires in Shivalik forest tracts of Uttarakhand by application of fire trends and Keetch Byram Drought Index [11528-20]

11528 OQ Meteorological data outlier detection: a principal component approach [11528-22]

\section{CLASSIFCATION}

$11528 \mathrm{OV}$ Investigating potato production in the future by the EU-28 countries using sentinels and EU open datasets [11528-27]

11528 OW Fuorescence spectral shape analysis for fast COVID-19 vinus identification: machine leaming approach [11528-40]

\section{POSTER SESSON}

11528 0X Ensuring the quality of aviation spraying of agric ultural airc raft with wind-powered drive [11528-28]

11528 oY Monitoring the dynamics of phenological development of winter wheat using orthogonalization of multispectral satellite data [11528-29]

1152813 Extracting knowledge from aenial photos based on the method of automated processing [11528-34]

1152814 Application of intelligent tec hnologies for getting information about the state of natural resources when monitoring the ecosystems of the northem temitories [11528-35] 